\title{
Influence of heat treatment of bovine skim-milk on in vivo digestion in rat stomach
}

\author{
G. MIRANDA, J.-P. PELISSIER \\ INRA, Laboratoire de Biochimie et Technologie laitières \\ 78350 Jouy-en-Josas, France
}

\begin{abstract}
Summary
The effect of heat treatment on in vivo gastric digestion of bovine milk proteins was studied on rats given skim-milk, UHT sterilized skim-milk and autoclaved skimmilk at $120^{\circ} \mathrm{C}$ during $20 \mathrm{~min}$. Stomach contents were analysed after 30, 60 and $240 \mathrm{~min}$ of digestion. The heat treatment resulted in an acceleration of the acidification of stomach contents and of gastric emptying rate and appeared to increase the hydrolysis of the caseins remaining into the stomach. These phenomena were all more prononced as the heat treatment was more important. With raw skim-milk the clotting of the diet induced a preferential emptying of whey proteins. After the heat treatment a slow down of gastric emptying of these proteins was observed. Consequently the amino acid composition of the stomach contents reached those of the whole whey during digestion time. $\beta$-lactoglobulin is resistant to the action of gastric proteinases although $\alpha$ lactalbumin, at favorable $\mathrm{pH}$ conditions, become susceptible to these enzymes.
\end{abstract}

Key words : Sterilized milk - UHT milk - In vivo digestion - Caseins - Whey - Stomach - Rat.

\section{Résumé}

Effet du chauffage sur la digestion in vivo des lactoprotéines bovines dans l'estomac du rat

L'effet du traitement thermique du lait de vache sur la digestion gastrique in vivo des protéines a été étudié chez des rats recevant du lait écrémé, du lait écrémé stérilisé par traitement UHT et du lait écrémé stérilisé à $120^{\circ} \mathrm{C}$ durant $20 \mathrm{~min}$. Le contenu stomacal a été prélevé 30,60 et $240 \mathrm{~min}$ après le repas. Le traitement thermique entraîne une accélération de l'acidification du contenu stomacal et de la vidange gastrique, ainsi qu'une intensification de la protéolyse des caséines restées dans l'estomac. Plus le traitement est important, plus les phénomènes sont sensibles. Avec le lait cru, la coagulation de l'aliment induit une vidange préférentielle des protéines du lactosérum. Après traitement thermique, la vidange de ces protéines est ralentie par rapport à celle des caséines. De ce fait, la composition en acides aminés du contenu stomacal se rapproche, au cours du temps, de celle du lactosérum. La $\beta$-lactoglobuline est résistante à l'action des protéases gastriques alors que l' $\alpha$-lactalbumine, dans des conditions de $\mathrm{pH}$ favorable, est dégradée par ces enzymes.

Mots clés : Lait stérilisé - Lait UHT - Digestion in vivo - Caséines - Lactosérum Estomac - Rat. 


\section{Introduction}

Milk covers an important part of the protein contribution in human feeding. Only a small part is consumed as raw milk, the most of it is undergoing different heat treatments, such as pasteurization, UHT sterilization... Heat treatment may also induce an alteration of the milk constituants (especially the proteic fraction) and of its physico-chemical properties. Appearance of molecular interactions between $\kappa$-caseins and $\beta$-lactoglobulin can be observed, which induce the stabilization of the micellar state of the caseins and thus an alteration of milk clotting (HINDLE and WHEELOCK, 1970; WILSON and WHEELOCK, 1972). The appearance of high molecular weight polymers by formation of covalent bonds between the caseins and whey proteins has also been observed (ANDREws, 1975). Heat treatment may induce an alteration of the mineral equilibrium of the milk (a decrease of soluble calcium) which reduces its clotting capacity (AlaIS, 1974). Heat treatment can modify the aspect of the coagulum : with pasteurized or UHT sterilized milk, it is less firm, granulous and thinless flocculent and has a lower dry matter content (Meisel and Hengemeister, 1984).

Heat alterations of milk are susceptible to induce modifications of in vivo digestion of the proteins. Gastric digestion of rats given a whole casein solution in water or in simulated milk ultrafiltrate (Miranda and PÉlissier, 1981) and skim milk (Miranda and Pélissier, 1983) was previously studied. It appears from these studies that the proteolytic activity of gastric proteinases is modified by some parameters such as $\mathrm{pH}$ of stomach contents, ionic strength or the amount of minerals in the diet. The rapid clotting of skim milk in the stomach induces a preferential emptying of whey proteins (MIRANDA and Pélissier, 1983). Caseins which are precipitated in the stomach are progressively hydrolyzed. The first degradation products, in vivo, are similar to those obtained by in vitro experiments (Delfour et al., 1965; Hill et al., 1974; Creamer et al., 1971; Visser and Slangen, 1977; Trieu-Cuot, 1981). The analysis of casein degradation products recovered into the duodenum of preruminant calves shows that all peptide bonds which are hydrolyzed in vivo are also hydrolyzed in vitro (Yvon et al., 1986).

In the present work, we describe the influence of different heat treatments on the in vivo gastric digestion of bovine milk proteins.

\section{Materials and methods}

\section{A. Diets}

The milk of a single cow, homozygous for the 4 caseins $\left(\alpha_{\mathrm{s} 1}-\mathrm{B}, \alpha_{\mathrm{s} 2}-\mathrm{A}, \beta-\right.$ $A 2, \kappa-A)$ and for the major whey proteins : $\beta$-lactoglobulin $B(\beta-\lg )$ and $\alpha$ lactalbumin A $(\alpha-$ la) was used to prepare 3 diets : skim-milk (M), UHT sterilized skim-milk $\left(140^{\circ} \mathrm{C}, 2 \mathrm{sec}\right)(\mathrm{U})$ and skim-milk autoclaved at $120^{\circ} \mathrm{C}$ during $20 \mathrm{~min}(\mathrm{~A})$. 


\section{B. Animals}

For the experiment 90 Wistar male rats (140-210 g) were sacrified (10 animals/diet/digestion time). Each animal, after one night fasting in individual anticoprophagy cages, was given $5 \mathrm{ml}$ of the diet by gastric intubation. It was then sacrified and its stomach content was recovered separately and analysed. Three digestion times were studied : 30,60 and $240 \mathrm{~min}$ after ingestion of the test meal.

\section{Analysis of samples}

The $\mathrm{pH}$ of the stomach contents was measured after homogenization with an Ultraturrax (Garrantlab, Paris, France). Then each stomach content was mixed with an equal volume of $24 \%$ trichloroacetic acid (TCA) to a final concentration of $12 \%$ TCA. The mixture was centrifuged at $2000 \mathrm{~g}$ for $20 \mathrm{~min}$. The sediment (protein fraction) and the supernatant (non protein fraction: NPN) were each extracted 10 times with about $5 \mathrm{ml}$ ethyl ether to eliminate the TCA, freeze-dried and separately analysed.

\section{Chemical analysis}

The amount of nitrogenous matters present in the stomach (protein fraction and NPN) was estimated by 2 methods: 1) total nitrogen (TN) determination with a Technicon II autoanalyzer (Technicon Instruments Corp., Tarrytown, New York 10591, U.S.A.). 2) amino acids nitrogen (AN) determination, after acid hydrolysis with $1.5 \mathrm{ml} 5.7 \mathrm{~N}-\mathrm{HCl}$ in evacuated and sealed test tubes for $24 \mathrm{~h}$ at $110^{\circ} \mathrm{C}$, with a Multichrom amino acid analyser (Beckman Instruments Inc., Palo Alto, Calif. 94304, U.S.A.). A qualitative analysis of the protein fraction of stomach contents was performed with two-dimensional gel electrophoresis according to TIEU-CuOT and GRIPON (1981).

\section{E. Statistical analysis}

Variance analysis (LISON, 1958) and principal component analysis (PCA) (HILl, 1974) were used to compare the results obtained with the different diets. In PCA, each sampling has been considered as a point in an ndimensional space with $\mathrm{n}$ variables. It is possible to describe this initial pattern in a two-dimensional space in which the 2 axes (corresponding to the new coordinates called factors) are not correlated. The new axes, or factors, can be interpreted in relation to the former variables by computing the loading of each variables on these factors. Thus, each point corresponding to a given sampling is represented in a two dimensional space defined by 2 factors ; 70$80 \%$ of the information contained in the data can be visualized on this plane. The smaller the distance from 2 points characteristic of sampling, the higher is the similitide of the 2 samplings. 


\section{Results}

\section{A. $p H$ of stomach contents}

$\mathrm{pH}$ determination of the different diets (table 1) indicated slight acidification of the milk after the heat treatment which was probably due to lactose degradation (AlAIS, 1974). Figure 1 shows the $\mathrm{pH}$ variation of the stomach contents with the different diets. There was no difference within the three diets $30 \mathrm{~min}$ after ingestion $(\mathrm{p}>0.05)$. However $\mathrm{pH}$ values (table 1) were significantly lower than those of the corresponding diet $(p<0.01)$. With sterilized milks ( $\mathrm{U}$ and $\mathrm{A}$ ), there was a significant decrease of $\mathrm{pH}(\mathrm{p}<0.01)$ between 30 and $60 \mathrm{~min}$ but not with raw milk (M). Sterilized milks resulted also in a lower $\mathrm{pH}$ than raw milk after 1 hour digestion. The difference was more important with diet $\mathrm{A}$ than with diet $\mathrm{U}$. pH of stomach contents was very low $240 \mathrm{~min}$ after ingestion. It was the same for diets $\mathrm{M}$ and $\mathrm{U}$ and significantly lower for diet A $(\mathrm{p}<0.01)$.

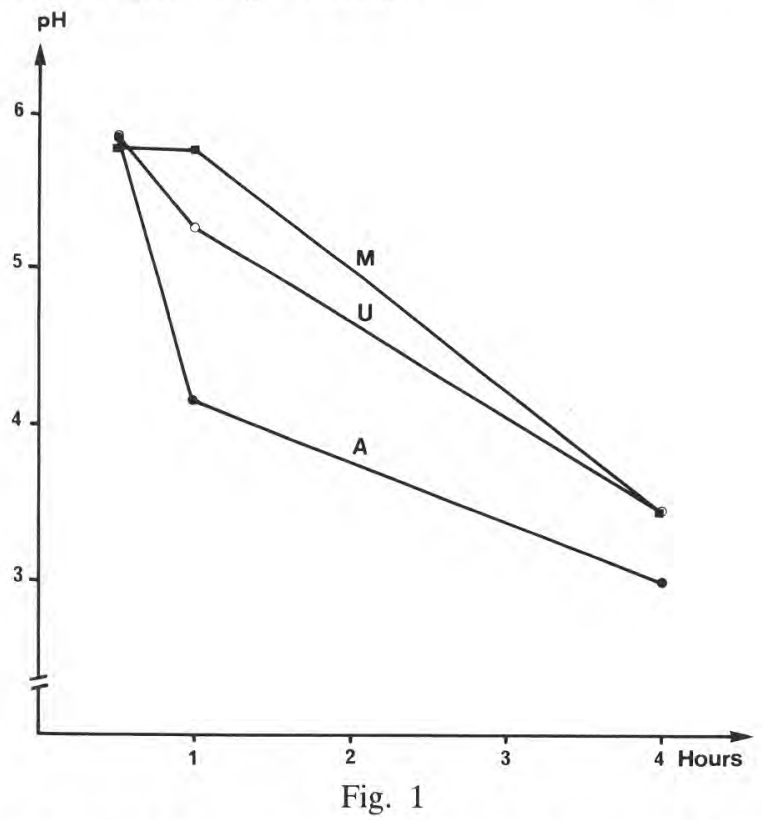

Change of $p H$ from stomach contents during digestion. $M$ : skim-milk, $U$ : UHT skimmilk, $A$ : autoclaved skim-milk.

Evolution du $p H$ moyen des contenus stomacaux au cours de la digestion. $M$ : lait écrémé, $U$ : lait écrémé UHT, $A$ : lait écrémé autoclavé.

\section{B. Gastric emptying}

Nitrogenous matter recovered in stomach contents at different digestion times, estimated by determination of total nitrogen (TN) or by determination of amino acid nitrogen (AN), is indicated in table 1. 
TABLE 1

Nitrogenous matter ( $m g \mathrm{~N} \times 6.39)$ present in stomach contents at the different digestion times.

Matière azotée $(m g N \times 6,39)$ présente dans les contenus stomacaux aux différents temps de digestion.

\begin{tabular}{|c|c|c|c|c|c|c|c|c|c|c|c|c|c|}
\hline \multicolumn{2}{|c|}{ Diet } & \multicolumn{4}{|c|}{ Raw skim milk } & \multicolumn{4}{|c|}{ UHT skim milk } & \multicolumn{4}{|c|}{ Autoclaved skim milk } \\
\hline \multicolumn{2}{|c|}{ Time (min) } & 0 & 30 & 60 & 240 & 0 & 30 & 60 & 240 & 0 & 30 & 60 & 240 \\
\hline $\mathrm{pH}$ & $\begin{array}{l}\mathrm{M} \\
\mathrm{SD} \\
\mathrm{VA}\end{array}$ & 6.73 & $\begin{array}{l}5.81 \\
0.363 \\
\mathrm{ab}\end{array}$ & $\begin{array}{l}5.78 \\
0.079 \\
\mathrm{a}\end{array}$ & $\begin{array}{c}3.46 \\
0.407 \\
c\end{array}$ & 6.65 & $\begin{array}{l}5.87 \\
0.260 \\
\text { b }\end{array}$ & $\begin{array}{l}5.27 \\
0.416\end{array}$ & $\begin{array}{l}3.46 \\
0.426 \\
c\end{array}$ & 6.51 & $\begin{array}{c}5.87 \\
0.045 \\
b\end{array}$ & $\begin{array}{l}4.15 \\
1.330\end{array}$ & $\begin{array}{l}3.00 \\
0.072\end{array}$ \\
\hline \multirow{3}{*}{ TNM (mg) } & $\underset{\mathrm{SD}}{\mathrm{MA}}$ & 147.8 & $\begin{array}{c}105.4 \\
26.05 \\
a b\end{array}$ & $\begin{array}{c}109.0 \\
24.35 \\
b\end{array}$ & $\begin{array}{c}88.9 \\
24.35 \\
\text { ac }\end{array}$ & 150.0 & $\begin{array}{l}95.5 \\
16.08 \\
\text { abde }\end{array}$ & $\begin{array}{r}76.2 \\
14.77 \\
\text { cefg }\end{array}$ & $\begin{array}{c}23.9 \\
13.29 \\
\text { hi }\end{array}$ & 139.7 & $\begin{array}{l}92.7 \\
19.72 \\
\text { abej }\end{array}$ & $\begin{array}{c}57.9 \\
17.28 \\
\mathrm{gk}\end{array}$ & $\begin{array}{c}34.0 \\
11.08 \\
\mathrm{~h}\end{array}$ \\
\hline & $\begin{array}{l}\mathrm{M} \\
\mathrm{SD} \\
\mathrm{VA}\end{array}$ & 126.9 & $\begin{array}{l}72.4 \\
17.61 \\
1\end{array}$ & $\begin{array}{c}74.5 \\
21.74 \\
1\end{array}$ & $\begin{array}{l}58.1 \\
19.34 \\
1 \mathrm{~m}\end{array}$ & 143.2 & $\begin{array}{c}77.4 \\
16.54 \\
\mathrm{dl}\end{array}$ & $\begin{array}{l}58.7 \\
25.13 \\
\quad \text { fl }\end{array}$ & $\begin{array}{l}20.7 \\
11.90 \\
\text { in }\end{array}$ & 133.0 & $\begin{array}{c}73.0 \\
27.46 \\
\text { j1 }\end{array}$ & $\begin{array}{l}39.9 \\
22.50 \\
\mathrm{kmn}\end{array}$ & $\begin{array}{l}20.1 \\
14.21 \\
n\end{array}$ \\
\hline & $\mathrm{AN} \%$ of $\mathrm{TN}$ & 85.8 & 68.7 & 68.3 & 65.3 & 95.4 & 81.0 & 77.0 & 86.6 & 95.2 & 78.7 & 68.9 & 59.1 \\
\hline \multirow{3}{*}{$\mathrm{PN}$ (mg) } & $\begin{array}{l}\mathrm{M} \\
\mathrm{SD} \\
\mathrm{VA}\end{array}$ & & $\begin{array}{c}85.1 \\
24.66 \\
\text { abc }\end{array}$ & $\begin{array}{c}94.1 \\
40.71 \\
\mathrm{c} \\
\end{array}$ & $\begin{array}{c}74.2 \\
35.25 \\
\mathrm{a} \\
\end{array}$ & & $\begin{array}{c}82.9 \\
17.97 \\
\text { ad }\end{array}$ & $\begin{array}{c}65.1 \\
13.24 \\
\text { aef }\end{array}$ & $\begin{array}{c}18.5 \\
12.88 \\
\text { gh }\end{array}$ & & $\begin{array}{c}71.9 \\
17.59 \\
\text { ai }\end{array}$ & $\begin{array}{c}44.8 \\
17.35 \\
\text { ejk }\end{array}$ & $\begin{array}{c}25.2 \\
10.81 \\
\text { gjl }\end{array}$ \\
\hline & $\begin{array}{lc}\mathrm{AN} & \mathrm{M} \\
\mathrm{SD} \\
\mathrm{VA}\end{array}$ & & $\begin{array}{l}66.5 \\
15.64 \\
\mathrm{bm}\end{array}$ & $\begin{array}{c}70.4 \\
21.78 \\
\mathrm{~m}\end{array}$ & $\begin{array}{c}52.7 \\
18.35 \\
\mathrm{mn}\end{array}$ & & $\begin{array}{c}69.9 \\
16.99 \\
\mathrm{dm}\end{array}$ & $\begin{array}{l}52.5 \\
20.80 \\
\text { fmo }\end{array}$ & $\begin{array}{c}17.8 \\
11.03 \\
\mathrm{~h}\end{array}$ & & $\begin{array}{l}64.0 \\
26.89 \\
\quad \text { im } \\
\end{array}$ & $\begin{array}{r}33.0 \\
21.40 \\
\text { kno }\end{array}$ & $\begin{array}{l}15.4 \\
12.45 \\
1\end{array}$ \\
\hline & $\mathrm{AN} \%$ of $\mathrm{TN}$ & & 78.1 & 74.9 & 71.1 & & 84.3 & 80.6 & 96.2 & & 89.0 & 73.6 & 61.1 \\
\hline \multirow{3}{*}{ NPN (mg) } & \begin{tabular}{cc|} 
& $\mathrm{M}$ \\
$\mathrm{TN}$ & $\mathrm{SD}$ \\
$\mathrm{VA}$
\end{tabular} & & $\begin{array}{c}20.3 \\
6.30 \\
a\end{array}$ & $\begin{array}{c}15.0 \\
4.47 \\
b\end{array}$ & $\begin{array}{c}14.8 \\
4.65 \\
b\end{array}$ & & $\begin{array}{c}12.6 \\
4.50 \\
\text { bc }\end{array}$ & $\begin{array}{l}11.1 \\
3.73 \\
\text { cde }\end{array}$ & $\begin{array}{l}5.4 \\
1.31 \\
\mathrm{fg}\end{array}$ & & $\begin{array}{c}20.8 \\
4.51 \\
\mathrm{a}\end{array}$ & $\begin{array}{c}13.1 \\
4.69 \\
\text { bd }\end{array}$ & $\begin{array}{l}8.8 \\
2.31 \\
\text { ef }\end{array}$ \\
\hline & $\begin{array}{l}\mathrm{M} \\
\mathrm{SD} \\
\mathrm{VA}\end{array}$ & & $\begin{array}{l}5.9 \\
2.19 \\
\text { hijn } \\
\end{array}$ & $\begin{array}{l}4.1 \\
1.46 \\
\text { hn }\end{array}$ & $\begin{array}{l}5.4 \\
1.95 \\
\mathrm{hn}\end{array}$ & & $\begin{array}{l}7.5 \\
3.71 \\
\text { ikop }\end{array}$ & $\begin{array}{c}6.2 \\
2.21 \\
\text { hklmn }\end{array}$ & $\begin{array}{l}2.9 \\
1.45 \\
\text { gln }\end{array}$ & & $\begin{array}{l}9.0 \\
4.68 \\
\text { jmo }\end{array}$ & $\begin{array}{l}6.9 \\
3.01 \\
\text { hno }\end{array}$ & $\begin{array}{l}4.7 \\
2.31 \\
\text { hnp }\end{array}$ \\
\hline & $\mathrm{AN} \%$ of $\mathrm{TN}$ & & 29.2 & 27.4 & 36.6 & & 59.5 & 55.8 & 53.7 & & 43.2 & 52.6 & 53.4 \\
\hline
\end{tabular}

$T N$ : total nitrogen, $A N$ : amino acid nitrogen, NPN : non protein fraction, $P N$ : protein fraction, TNM : total nitrogenous matter $(P N+N P N), M:$ average, $S D:$ standard deviation. VA: variance analysis. The values designated with the same letter are not significantly different $(p>0.05)$. Comparisons were made on the same line, in addition, for each sample $T N$ and $A N$ were compared at each digestion time.

$T N$ : azote total, $A N$ : azote des acides aminés, NPN : azote non protéique, TNM: matière azotée totale (NP + NPN), M : moyenne, SD : écart type, VA : analyse de variance, Les valeurs désignées par la même lettre ne sont pas significativement différentes ( $p>0,05)$. Les comparaisons ont été effectuées ligne par ligne, de plus, pour chacun des échantillons TN et AN ont été comparés à chaque temps de digestion. 
The results obtained by both methods were not significantly different $(p>0.05)$ for protein nitrogen $(P N)$, but they were different $(p<0.01)$ for the non protein fraction (NPN). This indicates the presence of a larger quantity of nitrogenous products in the non protein fraction which are neither small peptides nor free amino acids. They were probably coming, in a large extent, from endogenous secretions. According to Guilloteau et al. (1984), the amount of total nitrogen into the dry matter of the gastric juice, is about $20 \%$, the amino acid nitrogen representing $69 \%$ of total nitrogen matter. For this reason, in the absence of a diet marker, the best estimation of the amount of nitrogenous matter from dietary origin will be obtained by determination of amino acid nitrogen.

The total amino acid nitrogen (AN) (TCA sediment + TCA supernatant) found after $30 \mathrm{~min}$ was around $55 \%$ of intake with the three diets. It did not significantly change with the time with $\mathrm{M}$ diet but it was significantly lower $(\mathrm{p}<0.01)$ after 1 and 4 hours of digestion with $\mathrm{U}$ and $\mathrm{A}$ diets. This showed a faster gastric emptying with the two former diets (fig. 2).

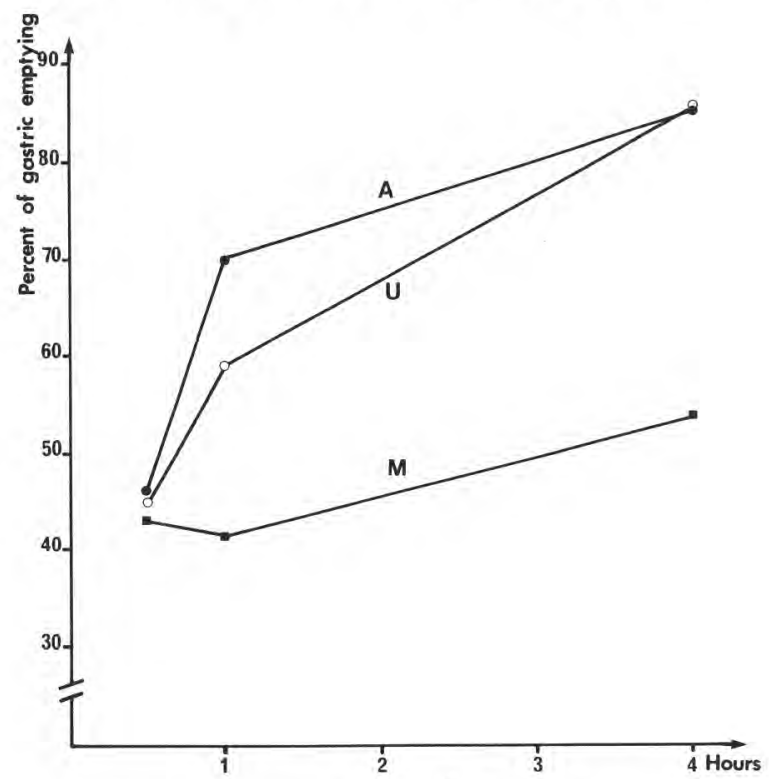

Fig. 2

Gastric emptying of total nitrogenous matter. Results expressed as percent of intake $15 \mathrm{ml}$ of diet). M: skim-milk, $U$ : UHT skim-milk, A : autoclaved skim-milk.

Vidange gastrique de la matière azotée totale. Résultats exprimés en pourcentage de l'ingéré $(5 \mathrm{ml}$ d'aliment). $M$ : lait écrémé, $U$ : lait écrémé $U H T, A$ : lait écrémé autoclavé.

\section{Degree of proteolysis}

The amount of NPN present in the stomach contents (fig. 3) is due to an equilibrium between proteolysis and gastric emptying. The level of proteolysis 
is under-estimated by this determination if the NPN is evacuated from stomach faster than protein nitrogen. Gastric emptying was similar with the three diets $30 \mathrm{~min}$ after feeding but it was faster thereafter with $\mathrm{U}$ and $\mathrm{A}$ diets. The proportion of NPN was greater at the 3 digestion times with the sterilized diets than with raw skim milk. This seems to indicate a more important gastric proteolysis with sterilized milks as soon as $30 \mathrm{~min}$ after feeding. The proteolysis of UHT skim milk occupies an intermediate position between raw skim milk and autoclaved skim milk.

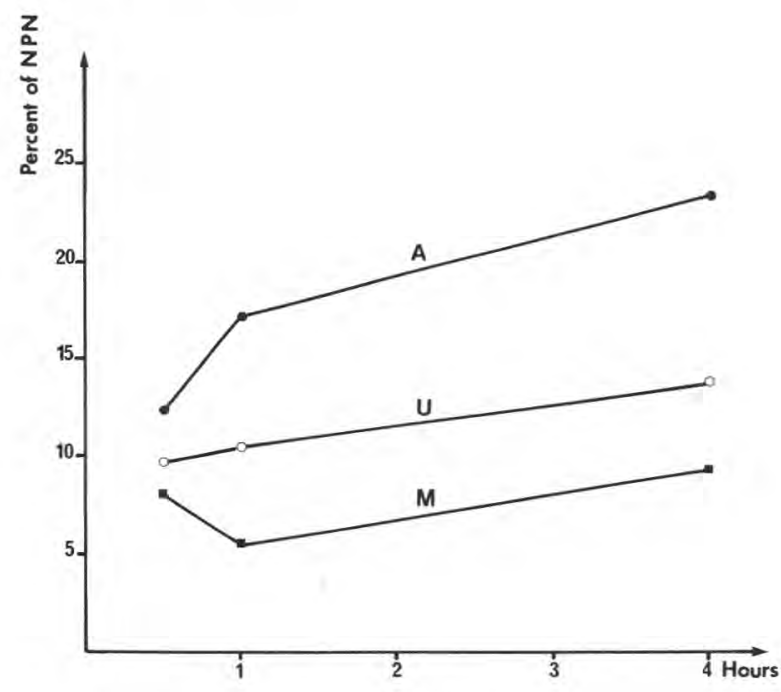

Fig. 3

NPN proportion of total amino acid nitrogen in stomach contents. Results expressed as percent of TNM. M : skim-milk, U: UHT skim-milk, A : autoclaved skim-milk.

Proportion de NPN dans l'azote total des acides aminés présent dans les contenus stomacaux. Résultats exprimés en pour cent de TNM. M: lait écrémé, U: lait écrémé $U H T, A$ : lait écrémé autoclavé.

\section{Two-dimensional electrophoresis of products present in the stomach}

With raw skim milk (fig. 4 b, c, d), there was a preferential gastric emptying of whey proteins $(\beta-\lg$ and $\alpha$-la). Thirty min after feeding, the ratio between caseins and whey proteins was more important than in the diet itself. $\beta-\lg$ was still visible on the gel but in very small quantities. Caseins were proteolysed with the appearance of $\alpha_{\mathrm{s} 1} \mathrm{I}$ and $\beta \mathrm{I}$ components (TRIEU-CUOT, 1981). A lot of low molecular weight degradation products could also be detected in a large zone of $\mathrm{pI}$ after 1 and 4 hours of digestion.

Although the electrophoretic patterns were similar with $M$ and $U$ diets (fig. $4 \mathrm{a}$ and $5 \mathrm{a}$ ), the degree of proteolysis at $30 \mathrm{~min}$ with UHT skim milk (fig. 5 b), was very close to that obtained after 240 min with raw skim milk (fig. $4 \mathrm{~d}$ ). With $\mathrm{U}$ diet we observed the presence of whey proteins in the 

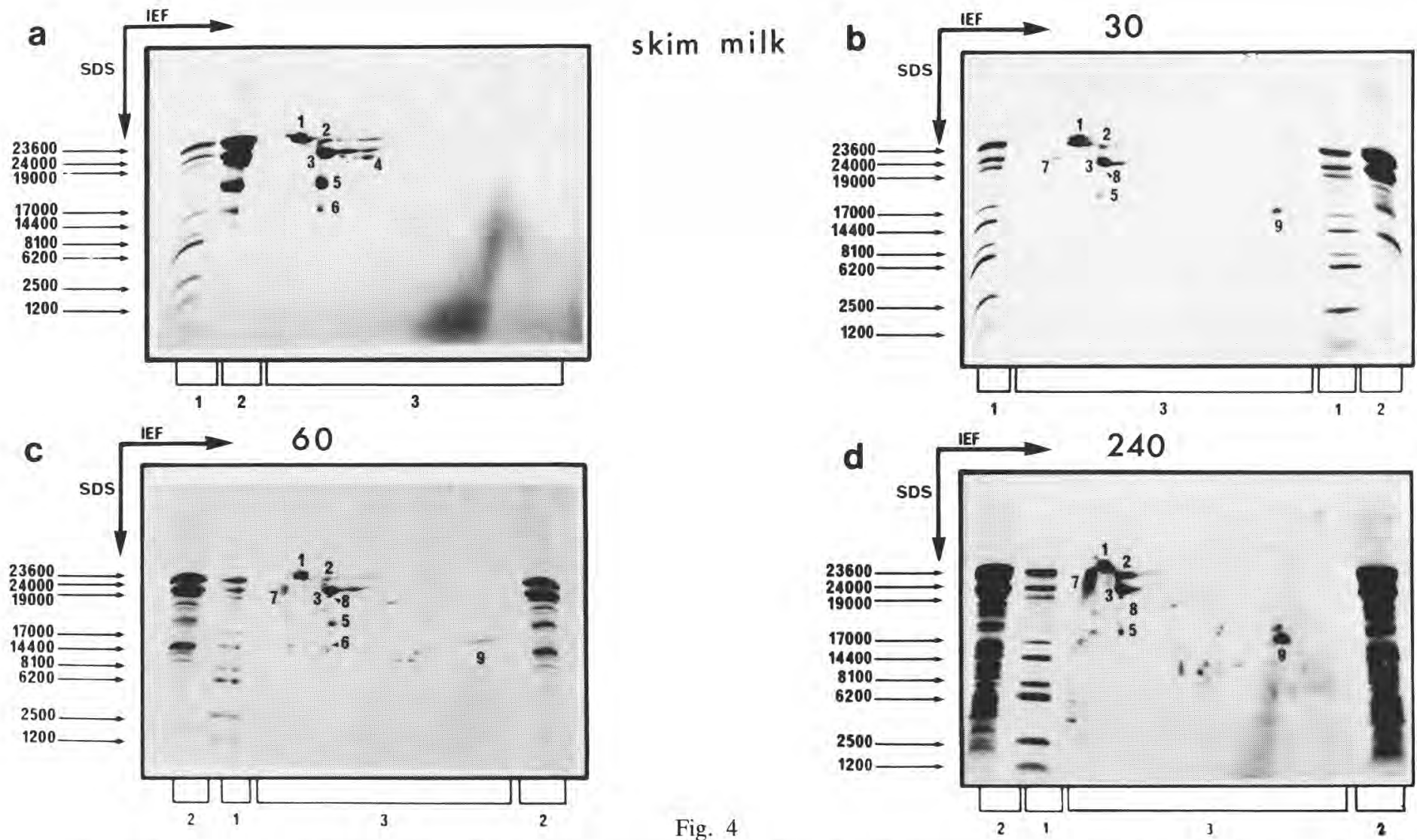

Raw skim milk. (1) molecular weight standard (SDS electrophoresis); SDS-electrophoresis (2) and two-dimensional electrophoresis

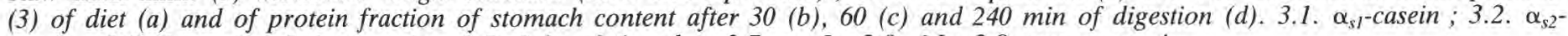

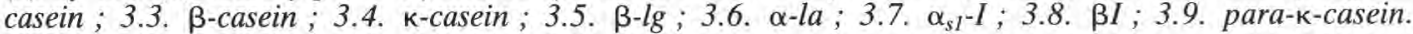

Lait écrémé cru. (1) standard de poids moléculaire (électrophorèse SDS) ; électrophorèse SDS (2) et bidimensionnelle (3) de l'aliment (a) et de la fraction protéique des contenus stomacaux après 30 (b), 60 (c) et $240 \mathrm{mn}$ de digestion (d). 

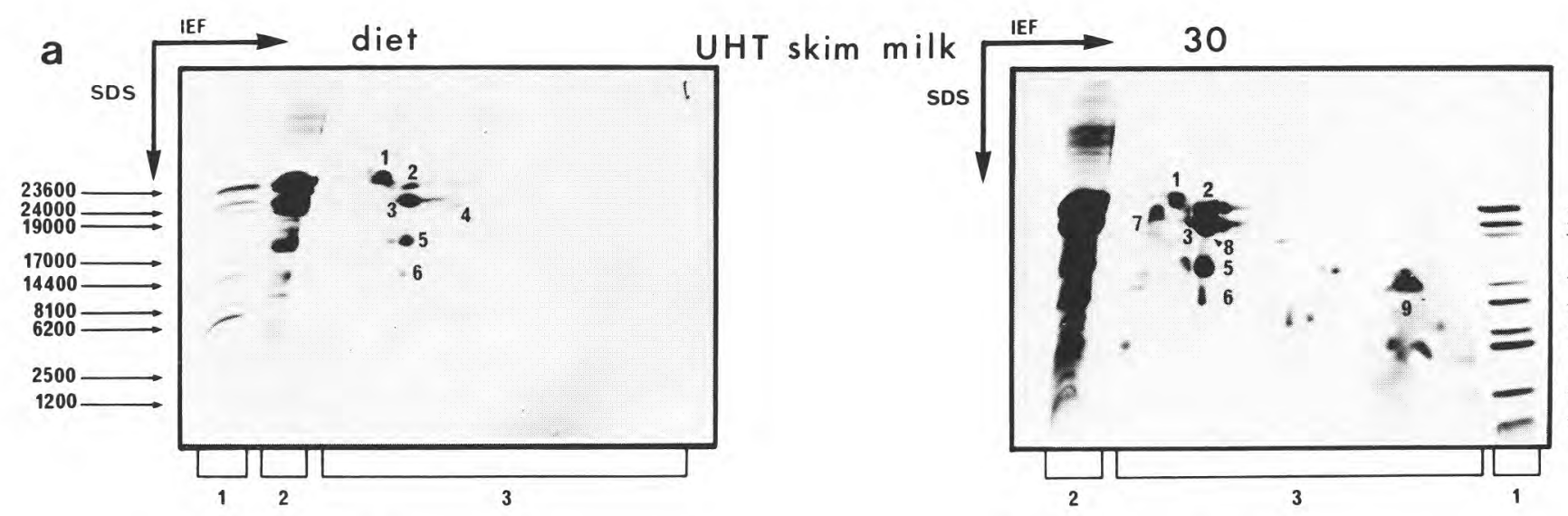

b

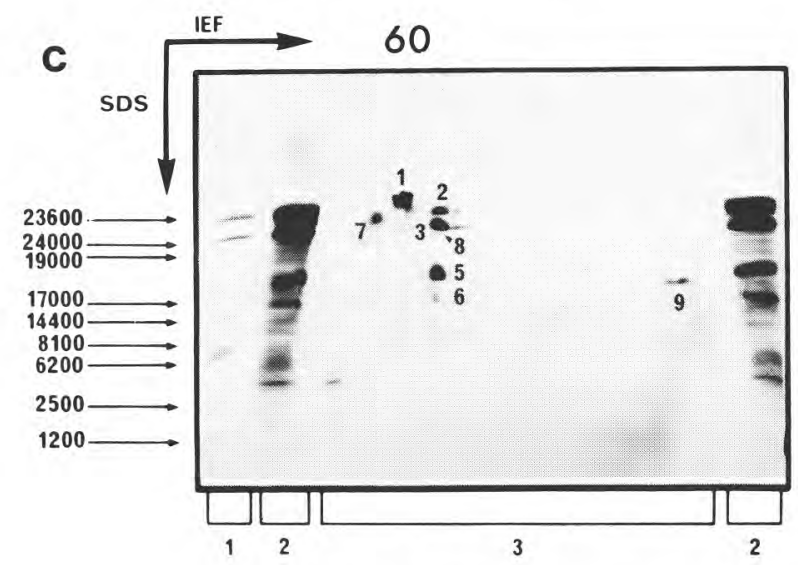

Fig. 5

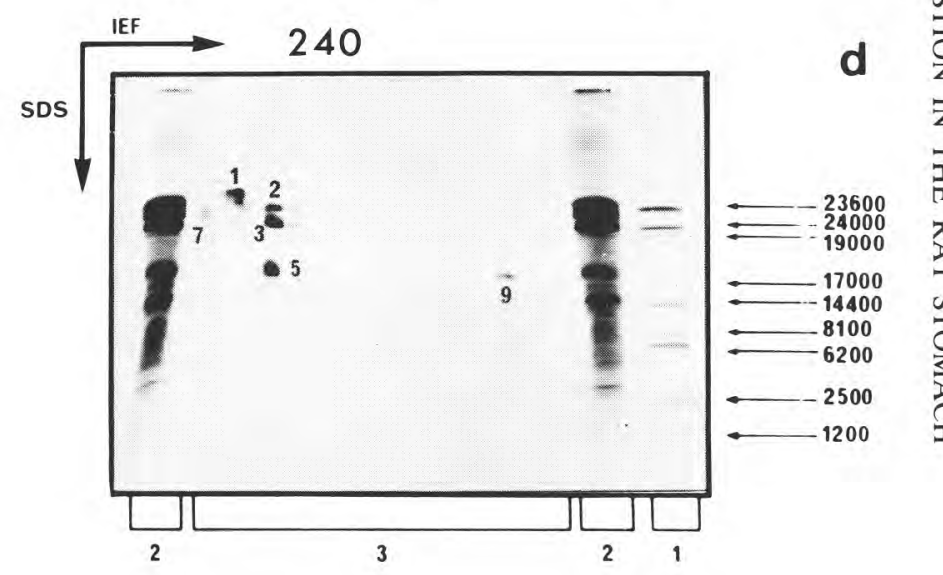

UHT skim milk. Legend see figure 5.

Lait écrémé UHT. Voir légende figure 5. 
stomach contents during the whole digestion process. This indicates no preferential gastric emptying of these proteins after heat treatment. $\beta-\lg$, no degraded or little proteolysed is still present in the stomach content after $240 \mathrm{~min}$ of digestion, but $\alpha$-la is no more detectable at this time. Although the latter is more resistant to gastric proteinases hydrolysis than caseins, it seems to be hydrolyzed by these enzymes under favorable $\mathrm{pH}$ conditions. This observation is in agreement with the work of Yvon et al. (1984).

With autoclaved skim milk (A), the modification of the diet was more important. Only $\alpha_{\mathrm{s} 1^{-}}$and $\beta$-casein were still visible while $\alpha_{\mathrm{s} 2^{-}}, \kappa$-casein, $\alpha$-la and $\beta-1 g$ were no more detectable on the gel. However, we observed the presence of a high molecular weight component at the origin, which could not enter into the gel. These products probably correspond to complex formation between caseins and the other milk components after heat treatment (ANDREWS, 1975).

\section{E. Amino acid composition of stomach contents}

Principal component analysis (fig. 6) using as variables the amino acid composition (17 amino acids $=17$ variables) of the protein fraction of the stomach contents, recovered at the different digestion times with the 3 diets, confirms observations made with two-dimensional electrophoresis.

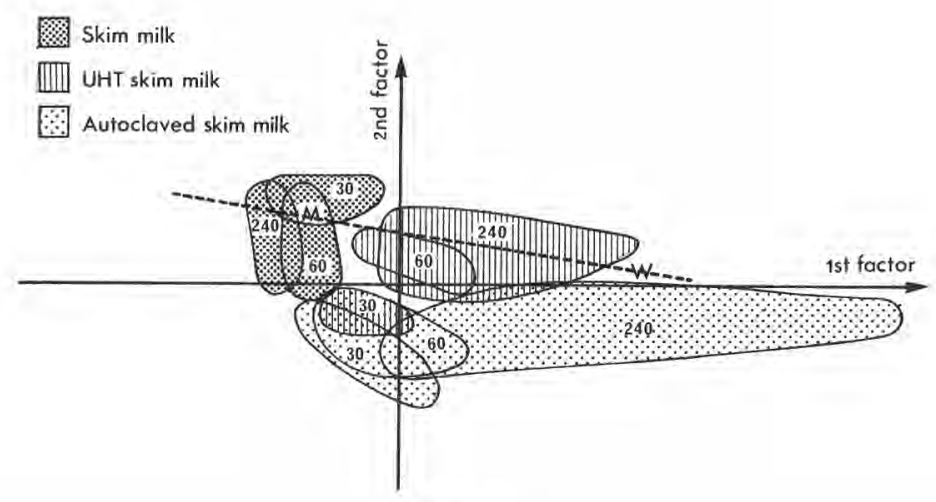

Fig. 6

Statistical analysis. Comparison at the 3 digestion times of the proteins fraction of stomach contents with the 3 diets, using as variables the amino acid composition (I7 variables). Graph of the first two factors extracted from PCA (see material and methods). Stomach contents recovered after $30 \mathrm{~min}(30), 60 \mathrm{~min}$ (60) and $240 \mathrm{~min}$ (240) of digestion. As references : amino acid composition of raw skim milk $(M)$ and whole whey $(W)$.

Analyse statistique. Comparaison aux trois temps de digestion de la fraction protéique des contenus stomacaux avec les trois régimes, en utilisant comme variables la composition en acides aminés (17 variables). Graphe des deux premiers facteurs obtenus par PCA (voir matériel et méthodes). Contenus stomacaux récupérés après $30 \mathrm{mn}$ (30), $60 \mathrm{mn}(60)$ et $240 \mathrm{mn}$ (240) de digestion. En référence: composition en acides aminés du lait écrémé cru $(M)$ et du lactosérum entier $(W)$. 
With raw milk the amino acid compositions at the different digestion times remained near to that of the diet $(\mathrm{M})$. With sterilized milks, they were nearer to that of whole whey (W). The more the time of digestion increased, the more the amino acid composition became closer to that of whey. This indicates an increase of the « whey proteins/caseins » ratio in the stomach.

On the other hand, at the 3 digestion times the amino acid compositions of stomach content with the A diet were located along the 2 nd factor under those of $\mathrm{U}$ and $\mathrm{M}$ diets. Along this factor, the separation is principaly due to lysine residues. The amino acid compositions of the 3 diets show a loss of lysine of about $3 \%$ with $\mathrm{U}$ diet and of about $11 \%$ with $\mathrm{A}$ diet, which was probably due to Maillard reactions during the heat treatment.

\section{Discussion}

The reduction of milk coagulability after heat treatment (HINDLE and Wheelock, 1950, Wilson and WHEelock, 1972, AlAis, 1974) can explain that gastric emptying was faster with the sterilized diets than with the unheated skim milk. These results are in agreement with those observed in mini pigs by Meisel and Heigemeister (1984). An increase of gastric emptying rate with an uncoagulable diet (whole whey) was also reported in preruminant calves (Toullec et al., 1971).

Heat treatment accelerates the acidification of stomach contents probably because of a faster decrease of the volume of the alimentary bolus. However, the effects of heat treatment on the in vivo digestion are not only limited to an increase of gastric emptying rate. We observe also an important increase of the hydrolysis of caseins corresponding to an increase of the NPN proportion in the stomach contents and to the appearance of many degradation products which were detected on electrophoresis. The increase of the proteolysis can be due at the same time to an acceleration of the acidification of the alimentary bolus which permits to come close to the optimal $\mathrm{pH}$ for the action of pepsins, and to the effect on caseins of the heat treatment itself. For example, LorienT et al. (1976) have observed an increase of the in vitro proteolytic activity of pepsins on $\alpha_{\mathrm{s} 1^{-}}$and $\beta$-casein solutions with the time of heating at $120^{\circ} \mathrm{C}$. However, if there was an increase of the percent of NPN relative to total N, this was not the case in absolute value. It is possible that the $\mathrm{N}$ of proteic fraction was evacuated faster from stomach with $\mathrm{U}$ and $\mathrm{A}$ diets than with $\mathrm{M}$ diet. In calves given heated milk (TerNOUTH et al., 1974) there was an increase of gastric emptying of total $\mathrm{N}$ and of the $\mathrm{N}$ of proteic fraction. However in our conditions it was not possible to verify the different hypothesis.

Heat treatment had also an influence of whey proteins. They were preferentially evacuated from the stomach with $M$ diet because they were expelled from the clot. However with the sterilized diets they were no more preferentially evacuated. On the contrary, we observed a slow down of their gastric emptying due to the fact that they are more resistant to gastric proteinases hydrolysis than caseins and that they form molecular interactions with the other milk proteins during heat treatment. For these reasons, the 
acceleration of caseins proteolysis, responsible for the appearance of peptides which are succeptible to be rapidly evacuated from the stomach, induces a modification of amino acid composition of stomach contents, which comes close to that of whole whey.

With $M$ and $U$ diets, $\alpha$-la disappeared from stomach contents $240 \mathrm{~min}$ after ingestion. This disappearance is in agreement with the studies of Yvon et al. (1984) on preruminant calves. These authors observed a disappearance of $\alpha$-la with the simultaneous appearance of two degradation products of different molecular weights. The susceptibility of $\alpha$-la to the action of gastric proteinases may be explained by a change of the conformation of the protein when the $\mathrm{pH}$ is lower than $\mathrm{pH} 4$ (KuWAJima, 1977).

\section{Conclusion}

Heat treatment of the milk leads to a modification of the in vivo digestion of bovine milk proteins. It induces an acceleration of gastric emptying rate of the total $\mathrm{N}$ and seems to increase caseins hydrolysis. The modification of milk clotting due to this treatment is responsible for a slow down of the gastric emptying rate of the whey proteins. Therefore, gastric digestion products and their kinetic of liberation in the small intestine will be modified after heat treatment.

Reçu le 7 juillet 1986.

Accepté pour publication le 13 décembre 1986.

\section{References}

Alais C., 1974. Science du lait, $3^{c}$ édition, Sep, Paris.

ANDREws A.T., 1975. Properties of aseptically packed ultra-high-temperature milk. III. Formation of polymerized protein during storage at various temperatures. J. Dairy Res., 42, 89-99.

Creamer L., Mills O.E., Richards E.L., 1971. The action of rennets on the casein. I. Rennin action on $\beta$-casein in solution. J. Dairy Res., 35, 269-280.

Delfour A., Jolles J., Alais C., Jolles P., 1965. Caseino-glycopeptides : characterization of methionine residue and the N-terminal sequence. Biochem. Biophys. Res. Commun., 19, 452 455 .

Gullloteau P., Corring T, Toullec R., Robelin J., 1984. Enzyme potentialities of the abomasum and pancreas of the calf. I. Effect of age in the preruminant. Reprod. Nutr. Develop., 24, 315-325.

Hill M.D., 1974. Correspondance analysis : a neglected multivariate method. Appl. Stat., 23, 340354.

Hill R., Lahay E., Givol. D., 1974. A rennin sensitive bond in $\alpha_{\mathrm{s} 1}$-B casein. J. Dairy Res., 41 , $147-153$.

Hindele E.J., Wheelock J.V., 1970. The primary phase of rennin action in heat sterilized milk. $J$. Dairy Res., 37, 389-396.

KuwaJima K., 1977. A folding model of $\alpha$-lactalbumin deduced from the three state denaturation mechanism. J. Mol. Biol., 114, 241-258. 
Lison L., 1958. Statistiques appliquées à la biologie. Paris, Gauthier-Villars.

Lorient D., Humbert G., Alais C., 1976. Dégradation thermique des caséines $\alpha$ s et $\beta$ de vache. III. Modification de la protéolyse enzymatique : relation avec la dégradation des acides aminés. Biochimie, 58, 871-873.

Meisel H., Hengemeister H., 1984. Zum Einfluss unterschiedlicher technologischer Behandlung von Milch auf die Verdauungsvorgänge im Magen. II. Magenpassage verschiedener Milchinhaltsstoffe. Milchwissenschaft, 39, 262-266.

Miranda G., Pelissier J.P., 1981. In vivo studies on the digestion of bovine caseins in the rat stomach. J. Dairy Res., 48, 319-326.

Miranda G., Pelissier J.P., 1983. Kinetic studies of in vivo digestion of bovine unheated skimmilk proteins in the rat stomach. J. Dairy Res., 50, 27-36.

Ternouth J.H., Roy J.H.B., Siddons R.C., 1974. Concurrent studies of the flow of digesta in the duodenum and exocrine pancreatic secretion of calves 2 . The effects of addition of fat to skim milk and of « severe» preheating treatment of spray-dried skim milk powder. Brit. J. Nutr., $31,13-26$.

Toullec R., Thivend P., Mathieu C.M., 1971. Utilisation des protéines du lactosérum par le veau préruminant à l'engrais. I. Vidange stomacale comparée du lait entier et de deux laits de remplacement ne contenant que des protéines du lactosérum comme source de matières azotées. Ann. Biol. Anim. Biochim. Biophys., 11, 435-543.

Trieu-Cuot P., 1981. Etude des caséines et de leurs produits de dégradation par méthode électrophorétique. Application à l'étude de l'affinage du Camembert. Thèse de $3^{\mathrm{e}}$ cycle. Université Paris XI. France.

Trieu-Cuot P., Gripon J.C., 1981. Electrofocusing and two-dimensional electrophoresis of bovine caseins. J. Dairy Res., 48, 303-310.

Visser S., Slangen K.J., 1977. On the specificity of chymosin (rennin) in its action on bovine $\beta$ casein. Neth. Milk Dairy J., 31, 16-30.

WiLson G.A., Wheelock J.V., 1972. Factors affecting the action of rennin in heated milk. $J$. Dairy Res., 39, 413-419.

Yvon M., Van Hille I., Pelissier J.P., Gullloteau P., Toullec R., 1984. In vivo milk digestion in the calf abomasum. II. Milk and whey proteolysis. Reprod. Nutr. Develop., 24, 835-843.

Yvon M., Pelissier J.P., Guilloteau P., Toullec R., 1986. Digestion des protéines du lait dans la caillette du veau préruminant. Reprod. Nutr. Dévelop., 26, 705-715. 